ISSN 0258-7122 (Print), 2408-8293 (Online)

Bangladesh J. Agril. Res. 44(1): 153-165, March 2019

\title{
EFFECTS OF ARBUSCULAR MYCORRHIZAL FUNGI, RHIZOBIUM AND PHOSPHORUS ON MUNGBEAN (Vigna radiata) IN SALINE SOIL
}

\author{
M. RAHMAN ${ }^{1}$, M. A. HOSSAIN ${ }^{2}$, M. E. ALI ${ }^{3}$ \\ M. F. A. ANIK ${ }^{4}$ AND F. ALAM
}

\begin{abstract}
A pot experiment was carried out in the nethouse of Soil Science Division of Bangladesh Agricultural Research Institute (BARI), Joydebpur, Gazipur in 2017 and 2018 with an objective to evaluate the potentiality of AM fungi, Rhizobium and $\mathrm{P}$ in different best combinations on germination (\%), growth, yield and yield contributing characters, nodulation, sporulation and nutrient concentration of mungbean under low salinity $\left(4 \mathrm{dSm}^{-1}\right)$ stress condition. The experiment was designed in CRD with 10 treatments and 4 replications. Mungbean variety BARI Mung-6 was used as a test crop. Peat based rhizobial inoculum (BARI RVr-403) was used in this experiment @ $50 \mathrm{~g} \mathrm{~kg}^{-1}$ seed and the population density of inoculum being above $10^{8} \mathrm{cfu} \mathrm{g}^{-1}$ inoculant. Soil based AM inoculum containing $275 \pm 20$ spores and infected root pieces of the host plant was used in each pot. There were 10 treatments viz. $\mathrm{T}_{1}$ : Control (Not absolute control), $\mathrm{T}_{2}$ : Arbuscular mycorrhiza $(\mathrm{AM})+50 \% \mathrm{P}, \mathrm{T}_{3}: \mathrm{AM}+75 \% \mathrm{P}, \mathrm{T}_{4}: \mathrm{AM}+100 \% \mathrm{P}, \mathrm{T}_{5}:$ Rhizobium $+50 \% \mathrm{P}, \mathrm{T}_{6}:$ Rhizobium $+75 \% \mathrm{P}, \mathrm{T}_{7}:$ Rhizobium $+100 \% \mathrm{P}, \mathrm{T}_{8}: \mathrm{AM}+$ Rhizobium $+50 \% \mathrm{P}, \mathrm{T}_{9}: \mathrm{AM}+$ Rhizobium $+75 \% \mathrm{P}$ and $\mathrm{T}_{10}: \mathrm{AM}+$ Rhizobium + $100 \%$ P. The highest seed yield $\left(2.28\right.$ g plant $^{-1}, 46.2 \%$ higher over control in 2017 and 2.97 g plant $^{-1}, 33.8 \%$ higher over control in 2018) and stover yield (5.23 $\mathrm{g} \mathrm{plant}^{-1}, 30.8 \%$ higher over control in 2017 and $5.67 \mathrm{~g} \mathrm{plant}^{-1}, 32.8 \%$ higher over control in 2018) were found in AM + Rhizobium $+75 \% \mathrm{P}$ treatment. Dual inoculation significantly increased $\mathrm{P}, \mathrm{S}, \mathrm{Mg}, \mathrm{Fe}, \mathrm{Mn}$ and $\mathrm{Zn}$ concentration of mungbean plant compared to control. The results suggest that inoculation of AM fungi and Rhizobium along with $75 \%$ of recommended $\mathrm{P}$ rate can help increased mungbean yield under low salinity stress condition through influence on nodulation, colonization and nutrient uptake.
\end{abstract}

Keywords: Nodulation, salinity, seed yield and nutrient content

\section{Introduction}

Soil salinity globally results in the greater loss in agricultural productivity. Over $30 \%$ of the cultivable area of Bangladesh lies in the coastal and offshore zones. Out of 2.86 million hectares of coastal and offshore lands, about 1.05 million hectares are affected by varying degrees of salinity (SRDI, 2010). Furthermore, the salinized areas are increasing at a rate of $10 \%$ annually for various reasons,

\footnotetext{
${ }^{1 \& 4}$ Scientific Officer, Soil Microbiology Laboratory, Bangladesh Agricultural Research Institute (BARI), Gazipur-1701, ${ }^{2}$ Chief Scientific Officer, Soil Science Division, BARI, Gazipur-1701, ${ }^{3 \& 5}$ Senior Scientific Officer, Soil Microbiology Laboratory, BARI, Gazipur-1701, Bangladesh.
} 
including low precipitation, high surface evaporation, weathering of native rocks, irrigation with saline water and poor cultural practices. It has been estimated that more than $50 \%$ of the arable land would be salinized by the year 2050 (Jamil et al., 2011).

Microorganisms specially arbuscular mycorrhiza have the potential to reduce the sodium and chloride toxicity in crops and that could be a more cost effective long term environmental friendly option. Arbuscular mycorrhizal fungi are pervasive and they are found in $80 \%$ of vascular plant families in existence today and fungi belonging to the order glomeromycota. Plants inoculated with mycorrhiza have been reported to improve plant growth and yield under salinity or $\mathrm{NaCl}$ stress conditions such as Ocimum basilicum (Ashoori et al., 2015) and Lens culinaris (Rahman et al., 2017). Rhizobium biofertilizer is a significant technology for improving crop productivity and soil fertility. It improves nodulation and as well as nitrogen fixation even under adverse soil conditions. Some studies are available on the double inoculation of $\mathrm{AM}$ and rhizobium under salinity condition increased yield of plants (Soliman et al., 2012). But there is no evidence of combined use of AM fungi and Rhizobium biofertilizer along with inorganic P fertilizer in the mitigation of soil salinity. It is known that very high and very low $\mathrm{P}$ levels may reduce mycorrhizal infection/colonization (Koide, 1991). It is also well established that infection by mycorrhizal fungi is significantly reduced at high soil $\mathrm{P}$ levels (Koide and $\mathrm{Li}, 1990$ ). Thus, we made intention to use $50 \%, 75 \%$ and $100 \% \mathrm{P}$ in the current experiment.

Mungbean (Vigna radiata) var. BARI Mung-6 is commonly used as an important pulse crop in Bangladesh. In 2016-2017, about 41,421 ha of land was under mungbean cultivation and the total production was about 34,783 metric tons (BBS, 2017). Mungbean may benefit from symbiotic association with mycorrhiza and rhizobium forming tripartite symbiosis. Keeping in view the above information, present investigation was undertaken to investigate the potential of AM fungi, Rhizobium and $\mathrm{P}$ on germination (\%), growth, yield and yield contributing characters, nodulation and nutrient concentration of mungbean plant under low salinity stress condition.

\section{Materials and Methods}

\section{Seed collection and soil preparation}

The experiment was carried out during kharif season from March to May 2017 and March to June 2018 in the nethouse of Soil Science Division, BARI, Joydebpur, Gazipur. Seeds of mungbean (BARI Mung-6) were collected from Pulses Research Centre, BARI, Gazipur. Bulk soil was collected from the bank of Turag river at Kodda, Gazipur. Soil was mixed with cowdung (Soil: Cowdung $=5: 1)$ for use in the pot experiment. Each pot $(28 \mathrm{~cm}$ in diameter and $23 \mathrm{~cm}$ in height) was filled with $8-\mathrm{kg}$ soil leaving upper 3 inches of pot vacant to facilitate watering. 


\section{Soil analysis}

Soil pH was measured by a combined glass calomel electrode (Jackson, 1958), organic carbon was determined by Wet Oxidation Method (Walkley and Black, 1934), total N by modified Kjeldahl method (Jackson, 1962), and Ca, K \& Mg by $\mathrm{NH}_{4} \mathrm{OAc}$ extraction method (Black, 1965). Copper, Fe, Mn and $\mathrm{Zn}$ were determined by DTPA extraction followed by AAS reading. Boron was determined by $\mathrm{CaCl}_{2}$ extraction method, $\mathrm{P}$ by Modified Olsen method (Olsen et al., 1954) and $\mathrm{S}$ by $\mathrm{CaH}_{4}\left(\mathrm{PO}_{4}\right)_{2} \cdot \mathrm{H}_{2} \mathrm{O}$ extraction method (Chesnin and Yien, 1950).

\section{Fertilizer application}

Chemical fertilizers @ $23 \mathrm{~kg} \mathrm{~N} \mathrm{ha}^{-1}$ from urea, $25 \mathrm{~kg} \mathrm{P}(100 \%) \mathrm{ha}^{-1}$ from TSP, 35 $\mathrm{kg} \mathrm{K} \mathrm{ha}{ }^{-1}$ from MoP, $8 \mathrm{~kg} \mathrm{~S} \mathrm{ha}^{-1}$ from gypsum, $2.25 \mathrm{~kg} \mathrm{Zn} \mathrm{ha}^{-1}$ from $\mathrm{ZnSO}_{4}, 0.81$ $\mathrm{kg} \mathrm{B} \mathrm{ha}{ }^{-1}$ from Boric acid and $0.34 \mathrm{~kg}$ Mo ha ${ }^{-1}$ from $\mathrm{Na}_{2} \mathrm{MoO}_{4} \cdot 2 \mathrm{H}_{2} \mathrm{O}$ were applied (BARC, 2012). Half of urea-N and all other fertilizers were applied as basal and the remaining half was applied after 10 days of sowing. There were three P levels: $50 \%, 75 \%$ and $100 \%$ P. Peat based rhizobial inoculum (BARI $\mathrm{RVr}-403$ ) was used in this experiment @ $50 \mathrm{~g} \mathrm{~kg}^{-1}$ seed and in that case $\mathrm{N}$ fertilizer was not used. The population density of used inoculum was above $10^{8}$ cfu g ${ }^{-1}$ inoculant.

\section{Preparation of salinity solution and mycorrhizal inoculum}

Required concentrations of salinity were prepared according to New South Wales (NSW), Australia and applied three times during the experimentation period (Before seed sowing, 25 DAS and 35 DAS to maintain salinity level at $4 \mathrm{dSm}^{-1}$ ). The arbuscular mycorrhizal inoculum was prepared from the roots and rhizosphere soils of Sorghum. Mycorrhizal species was originally isolated from different AEZs using the wet sieving and decanting method (Gerdemann and Nicolson, 1963). The spores mixed soil were put in the bed of sorghum plants to multiply for 6 months in the nethouse of Soil Science Division, BARI. Plants were irrigated with tap water as needed. A mixture of infected sorghum root and soil which contained spores was used as mycorrhizal inoculum. Dominant mycorrhizal spores were from the genera Glomus, Acaulospora, Gigaspora and Scutellospora. The soil based AM fungal inoculum containing $150 \mathrm{~g}$ of rhizosphere soil (approximate $183 \pm 20$ spores/100 g soil) along with infected sorghum root fragments with a minimum infection level was inoculated to each mycorrhizal pot. Different mycorrhizal spores identified in the Soil Microbiology Laboratory, Soil Science Division, BARI and used for the experiment were shown in Figure 1. The mycorrhizal inoculum was placed in each pot at $3-5 \mathrm{~cm}$ depth and was covered with a thin soil layer of $1 \mathrm{~cm}$ immediately prior to the seed sowing of mungbean to facilitate AM colonization of plant roots. 


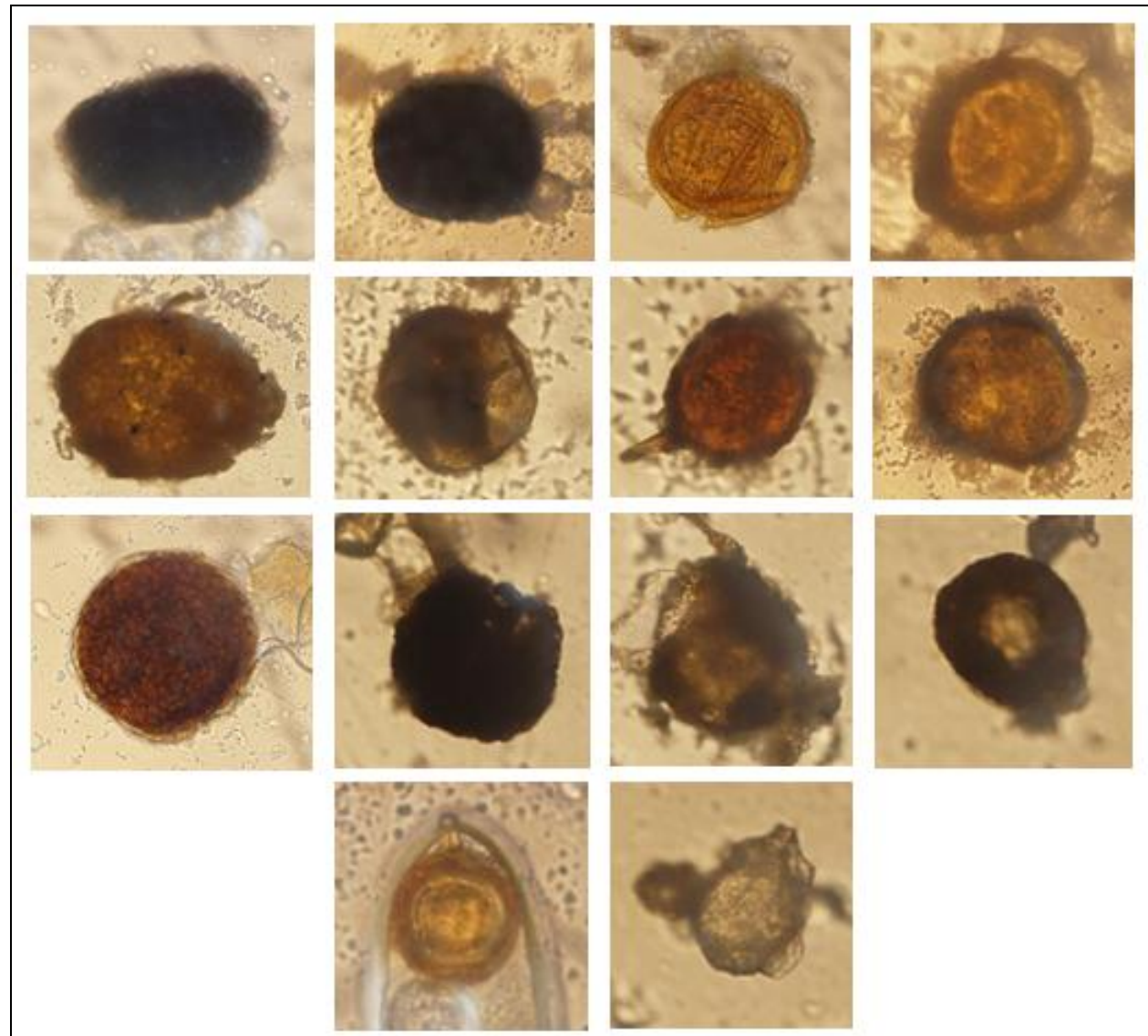

Figure 1. Different mycorrhizal spore (Glomus, Acaulospora, Gigaspora and Scutellospora spp) identified in the Soil Microbiology Laboratory, Soil Science Division, BARI and used for the experiment.

\section{Identification of AM fungal spore}

AM fungal spore, single spore or sporocarps were easily picked up from the Petridis by filter paper with the help of syringe or fine point camel brush and mounted on a glass slide with a drop of polyvinyl lactophenol (PVL) and a cover slip was placed. Subsequently, recovered spores were identified with the help of a Manual and different taxonomic keys proposed by different workers (Schwarzott et al., 2001). Spore morphology, size, shape and peridium of spore, sporocarps colour, wall ornamentation, subtending hyphae and mode of attachment are considered for identification of spore or sporocarps.

\section{Design of experiment and treatments}

The experiment was designed in CRD with 10 treatments and 4 replications. There were 10 treatments viz. $\mathrm{T}_{1}$ : Control (Not absolute control), $\mathrm{T}_{2}$ : Arbuscular 
mycorrhiza $(\mathrm{AM})+50 \% \mathrm{P}, \mathrm{T}_{3}: \mathrm{AM}+75 \% \mathrm{P}, \mathrm{T}_{4}: \mathrm{AM}+100 \% \mathrm{P}, \mathrm{T}_{5}:$ Rhizobium $+50 \% \mathrm{P}, \mathrm{T}_{6}:$ Rhizobium $+75 \% \mathrm{P}, \mathrm{T}_{7}:$ Rhizobium $+100 \% \mathrm{P}, \mathrm{T}_{8}: \mathrm{AM}+$ Rhizobium $+50 \% \mathrm{P}, \mathrm{T}_{9}: \mathrm{AM}+$ Rhizobium $+75 \% \mathrm{P}$ and $\mathrm{T}_{10}: \mathrm{AM}+$ Rhizobium + $100 \% \mathrm{P}$. Ten seeds were sown in each pot beneath $1 \mathrm{~cm}$ soil depth. After collecting germination percentage data, 6 vigorous seedlings were kept in each treatment and other seedlings were removed from the pot. Three plants of each were collected for nodulation and colonization data and rest three plants were kept finally in each pot for yield and yield contributing measurements.

\section{Determination of germination percentage}

The germination test was carried out according to ISTA rules (ISTA, 1976). For each treatment, 25 seeds were put into Petri dishes. The Petri dishes were put on a laboratory table at room temperature $\left(28 \pm 2^{\circ} \mathrm{C}\right)$. After 3 days, normal, abnormal and diseased seeds were counted. Germination of mungbean seed in the laboratory table was $84 \%$. Ten seeds were sown in each pot. After 4, 6, 8 and 10 days germinated seeds were observed and counted.

\section{Crop harvest}

Mungbean was harvested after 62 days of sowing. Different growth parameters like plant height, pods plant ${ }^{-1}$, seeds pod $^{-1}, 100$-seed weight, seed yield and stover yield were recorded. Other parameters like nodule number, nodule weight and root infection (\%) were measured at the time of $50 \%$ flowering stage of mungbean.

\section{Assessment of root colonization infection}

The percentage of AM infection was estimated by root slide technique (Read et al., 1976). One hundred root segments were examined for each sample. The stained root pieces were mounted in acidic glycerol on slides and the cover slip was placed by slightly pressed. The roots were observed under microscope. A root segment was considered as positively infected, if it showed mycelium, vesicles and arbuscules or any other combination of these structural characteristics of AM infection. The presence or absence of infection in the root pieces was recorded and the percent infection was calculated.

Table 1. Initial fertility status of soil and cowdung used in the experimental pot

\begin{tabular}{|c|c|c|c|c|c|c|c|c|c|c|c|c|c|c|}
\hline \multirow{2}{*}{ Samples } & \multirow{2}{*}{ Texture } & \multirow{2}{*}{$\mathrm{pH}$} & \multirow{2}{*}{$\begin{array}{l}\text { OM } \\
(\%)\end{array}$} & $\mathrm{Ca}$ & $\mathrm{Mg}$ & $\mathrm{K}$ & \multirow{2}{*}{$\begin{array}{c}\text { Total } \\
\mathrm{N} \\
(\%)\end{array}$} & $P$ & $S$ & B & $\mathrm{Cu}$ & $\mathrm{Fe}$ & $\mathrm{Mn}$ & $\mathrm{Zn}$ \\
\hline & & & & me & q 100 & $\mathrm{~g}^{-1}$ & & \multicolumn{7}{|c|}{$\mu \mathrm{g} \mathrm{g}^{-1}$} \\
\hline Soil & Sandy clay loam & 7.1 & 0.51 & 7.2 & 2.5 & 0.11 & 0.026 & 9.9 & 21.1 & 0.22 & 1.8 & 15 & 1.1 & 0.38 \\
\hline Cowdung & - & 6.7 & 14.1 & 1.55 & 0.82 & 0.88 & 0.84 & 1.26 & 0.62 & 0.02 & 0.01 & 0.25 & 0.11 & 0.02 \\
\hline Critical level & - & - & - & 2.0 & 0.5 & 0.12 & - & 10 & 10 & 0.20 & 0.2 & 4.0 & 1.0 & 0.60 \\
\hline
\end{tabular}




\section{Statistical analysis}

Data were statistically analyzed using Analysis of Variance (ANOVA) following CropStat package while the all pair comparisons were done by Statistix 10.

\section{Results and Discussion}

\section{Effects of AM, Rhizobium and $P$ on germination of mungbean}

Effect of AM, Rhizobium and P on germination of mungbean have presented in Table 2 and Fig. 2. Significant differences were found in case of germination in 2017, not in 2018. The highest germination was found in the AM + Rhi. $+100 \%$ $\mathrm{P}$ treatment and the lowest germination in the control treatment.

Table 2. Effects of AM, Rhizobium and $P$ on germination of mungbean in $4 \mathrm{dSm}^{-1}$ saline soil

\begin{tabular}{|c|c|c|c|c|c|c|}
\hline \multirow{3}{*}{ Treatments } & \multicolumn{6}{|c|}{ Germination $(\%)$} \\
\hline & \multicolumn{2}{|c|}{4 DAS } & \multicolumn{2}{|c|}{$6 \mathrm{DAS}$} & \multicolumn{2}{|c|}{$8 \mathrm{DAS}$} \\
\hline & 2017 & 2018 & 2017 & 2018 & 2017 & 2018 \\
\hline Control & $52.5 \mathrm{~d}$ & 45.0 & $75.0 \mathrm{bc}$ & 72.5 & $75.0 \mathrm{a}$ & 72.5 \\
\hline $\mathrm{AM}+50 \% \mathrm{P}$ & $65.0 \mathrm{bcd}$ & 52.5 & $80.0 \mathrm{abc}$ & 70.0 & $80.0 \mathrm{abc}$ & 72.5 \\
\hline $\mathrm{AM}+75 \% \mathrm{P}$ & $60.0 \mathrm{~cd}$ & 65.0 & $75.0 \mathrm{bc}$ & 80.0 & $75.0 \mathrm{c}$ & 82.5 \\
\hline $\mathrm{AM}+100 \% \mathrm{P}$ & $60.0 \mathrm{~cd}$ & 55.0 & $70.0 \mathrm{c}$ & 85.0 & $77.5 b c$ & 87.5 \\
\hline Rhi. $+50 \% \mathrm{P}$ & $82.5 \mathrm{a}$ & 62.5 & $85.0 \mathrm{ab}$ & 72.5 & $90.0 \mathrm{a}$ & 75.0 \\
\hline Rhi. $+75 \% \mathrm{P}$ & $80.0 \mathrm{ab}$ & 67.5 & $87.5 \mathrm{a}$ & 77.5 & $90.0 \mathrm{a}$ & 82.5 \\
\hline$R h z .+100 \% \mathrm{P}$ & $75.0 \mathrm{abc}$ & 65.0 & $77.5 \mathrm{abc}$ & 77.5 & $82.5 \mathrm{abc}$ & 80.0 \\
\hline $\mathrm{AM}+R h i .+50 \% \mathrm{P}$ & $80.0 \mathrm{ab}$ & 60.0 & $87.5 \mathrm{a}$ & 72.5 & $90.0 \mathrm{a}$ & 77.5 \\
\hline $\mathrm{AM}+R h i .+75 \% \mathrm{P}$ & $70.0 \mathrm{abc}$ & 57.5 & $85.0 \mathrm{ab}$ & 75.0 & $85.0 \mathrm{abc}$ & 75.0 \\
\hline $\begin{array}{l}\mathrm{AM}+\text { Rhi. }+100 \% \\
\mathrm{P}\end{array}$ & $80.0 \mathrm{ab}$ & 57.5 & $87.5 \mathrm{a}$ & 77.5 & $87.5 \mathrm{ab}$ & 75.0 \\
\hline $\mathrm{SE}( \pm)$ & 5.36 & 6.26 & 4.24 & 5.86 & 4.08 & 5.14 \\
\hline F-test & $* *$ & NS & $*$ & NS & $*$ & NS \\
\hline $\mathrm{CV}(\%)$ & 15.2 & 21.3 & 10.5 & 15.4 & 9.80 & 13.2 \\
\hline
\end{tabular}

AM: Arbuscular mycorrhiza, Rhi.: Rhizobium. Control is not absolute control. The values represent means of 4 replicates. Different letters within each column indicate significant differences between treatments. Test CropStat and Statistix 10. **Significant $\mathrm{P} \leq 0.01$, *significant $\mathrm{P} \leq 0.05$, NS not significant 


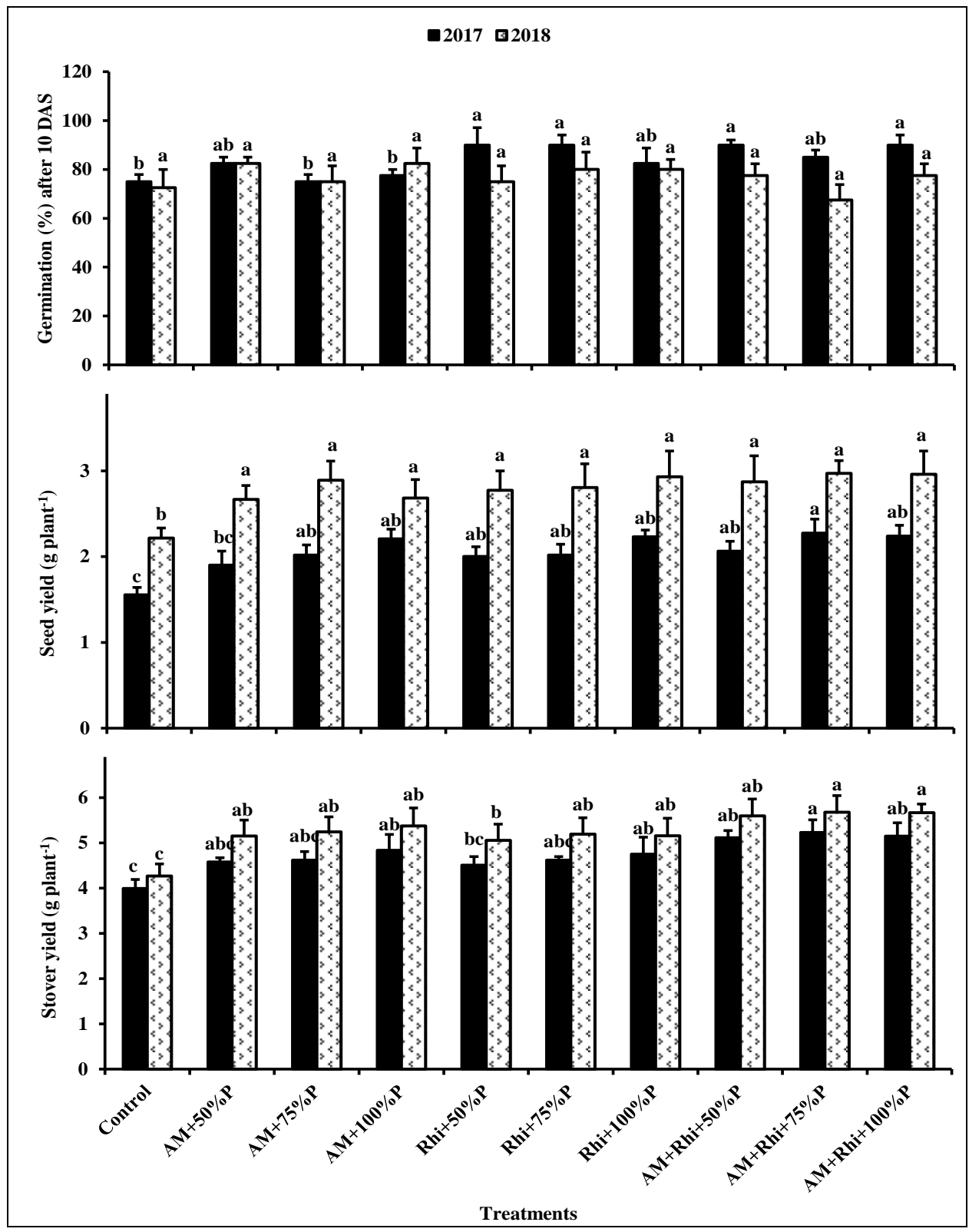

Fig. 2. Effects of AM, Rhizobium and $P$ on germination (\%), seed yield and stover yield of mungbean in slightly saline soil during 2017 and 2018.

High salt concentrations can reduce seed germination and initial seedling growth, as well as the growth of established plants (Zedler et al., 2003). Mendez et al. (2015) reported that salinity stress reduced both seed germination and seedlings growth of Phaseolus vulgaris at salt concentrations above $150 \mathrm{mM}$. Beneficial 
effect of AM fungi and Rhizobium in soil would be due to creation of soil conditions suitable for the growth of hyphae and increased microbial activity.

\section{Effects of AM, Rhizobium and P on plant height, yield and yield attributes of mungbean}

Effects of AM, Rhizobium and $\mathrm{P}$ on plant height, yield and yield attributes of mungbean are shown in Table 3 and Fig. 2. Seed yield $\left(\mathrm{g} \mathrm{pot}^{-1}\right)$ and stover yield $\left(\mathrm{g} \mathrm{pot}^{-1}\right)$ was significant but statistically identical with rest of the treatments except control while the plant height, yield and yield attributes were not significant. The highest seed yield $\left(2.28 \mathrm{~g} \mathrm{plant}^{-1}, 46.2 \%\right.$ higher over control in 2017 and $2.97 \mathrm{~g} \mathrm{plant}^{-1}, 33.8 \%$ higher over control in 2018) and stover yield (5.23 g plant $^{-1}, 30.8 \%$ higher over control in 2017 and 5.67 g plant $^{-1}, 32.8 \%$ higher over control in 2018) were found in $\mathrm{AM}+$ Rhizobium $+75 \% \mathrm{P}$ treatment. On the other hand, lowest seed yield (1.56 g plant ${ }^{-1}$ in 2017 and $2.22 \mathrm{~g} \mathrm{plant}^{-1}$ in 2018) and stover yield (4.00 g plant ${ }^{-1}$ in 2017 and 4.27 g plant $^{-1}$ in 2018) were found in control treatment.

Table 3. Effects of AM, Rhizobium and $P$ on plant height, yield and yield attributes of mungbean in $4 \mathrm{dSm}^{-1}$ saline soil

\begin{tabular}{|c|c|c|c|c|c|c|c|c|c|c|c|c|}
\hline \multirow[t]{2}{*}{ Treatments } & \multicolumn{2}{|c|}{$\begin{array}{c}\text { Plant height } \\
(\mathrm{cm})\end{array}$} & \multicolumn{2}{|c|}{ Pods plant ${ }^{-1}$} & \multicolumn{2}{|c|}{ Seeds pod ${ }^{-1}$} & \multicolumn{2}{|c|}{$\begin{array}{c}100 \text {-seed } \\
\text { weight }(\mathrm{g})\end{array}$} & \multicolumn{2}{|c|}{$\begin{array}{c}\text { Seed yield } \\
\text { increase } \\
\text { over control } \\
(\%)\end{array}$} & \multicolumn{2}{|c|}{$\begin{array}{l}\text { Stover yield } \\
\text { increase } \\
\text { over control } \\
(\%)\end{array}$} \\
\hline & 2017 & 2018 & 2017 & 2018 & 2017 & 2018 & 2017 & 2018 & 2017 & 2018 & 2017 & 2018 \\
\hline Control & 25.0 & 30.7 & 4.75 & 6.75 & 6.80 & 8.20 & 4.92 & 4.59 & - & - & - & - \\
\hline $\mathrm{AM}+50 \% \mathrm{P}$ & 27.2 & 31.9 & 5.50 & 8.65 & 8.00 & 8.90 & 5.24 & 5.47 & 21.8 & 20.3 & 14.5 & 20.6 \\
\hline $\mathrm{AM}+75 \% \mathrm{P}$ & 27.5 & 32.3 & 5.92 & 8.50 & 8.30 & 9.20 & 5.26 & 5.42 & 29.5 & 30.2 & 15.5 & 22.7 \\
\hline $\mathrm{AM}+100 \% \mathrm{P}$ & 27.9 & 31.8 & 6.17 & 7.82 & 8.40 & 8.90 & 5.40 & 5.40 & 41.7 & 20.7 & 21.0 & 25.8 \\
\hline$R h i .+50 \% \mathrm{P}$ & 27.5 & 31.8 & 5.83 & 6.90 & 7.50 & 9.30 & 5.36 & 4.62 & 28.9 & 24.8 & 12.8 & 18.5 \\
\hline$R h i .+75 \% \mathrm{P}$ & 28.0 & 32.3 & 5.92 & 8.00 & 7.60 & 9.40 & 5.44 & 4.64 & 29.5 & 26.6 & 15.5 & 21.6 \\
\hline Rhiz. $+100 \% \mathrm{P}$ & 29.0 & 31.8 & 6.25 & 7.75 & 8.25 & 9.35 & 5.44 & 5.65 & 43.0 & 32.0 & 18.8 & 20.8 \\
\hline $\begin{array}{l}\mathrm{AM}+R h i .+ \\
50 \% \mathrm{P}\end{array}$ & 27.6 & 32.3 & 5.92 & 7.78 & 8.15 & 9.50 & 5.42 & 5.11 & 32.7 & 29.3 & 28.0 & 30.9 \\
\hline $\begin{array}{l}\mathrm{AM}+R h i .+ \\
75 \% \mathrm{P}\end{array}$ & 28.8 & 32.0 & 5.92 & 8.50 & 8.80 & 9.50 & 5.46 & 5.53 & 46.2 & 33.8 & 30.8 & 32.8 \\
\hline $\begin{array}{l}\mathrm{AM}+\text { Rhi. }+ \\
100 \% \mathrm{P}\end{array}$ & 29.7 & 32.7 & 6.25 & 8.50 & 8.45 & 9.70 & 5.46 & 5.36 & 43.6 & 33.3 & 28.8 & 32.6 \\
\hline $\mathrm{SE}( \pm)$ & 1.46 & 0.88 & 0.32 & 0.55 & 0.44 & 0.43 & 0.09 & 0.41 & - & - & - & - \\
\hline F-test & NS & NS & NS & NS & NS & NS & NS & NS & - & - & - & - \\
\hline $\mathrm{CV}(\%)$ & 7.40 & 5.49 & 11.1 & 13.9 & 11.0 & 9.25 & 6.90 & 11.1 & - & - & - & - \\
\hline
\end{tabular}

AM: Arbuscular mycorrhiza, Rhi.: Rhizobium. Control is not absolute control. The values represent means of 4 replicates. Different letters within each column indicate significant differences between treatments. Test CropStat and Statistix 10. NS not significant 
Table 4. Effects of AM, Rhizobium and $P$ on nutrient concentration of mungbean in $4 \mathrm{dSm}^{-1}$ saline soil

\begin{tabular}{|c|c|c|c|c|c|c|c|c|c|c|c|}
\hline \multirow{3}{*}{ Treatments } & \multicolumn{11}{|c|}{ Nutrient concentration } \\
\hline & $\mathrm{N}$ & $\mathrm{P}$ & $\mathrm{K}$ & $S$ & $\mathrm{Ca}$ & $\mathrm{Mg}$ & B & $\mathrm{Cu}$ & $\mathrm{Fe}$ & $\mathrm{Mn}$ & $\mathrm{Zn}$ \\
\hline & \multicolumn{6}{|c|}{$\%$} & \multicolumn{5}{|c|}{ ppm } \\
\hline Control & 2.26 & $0.46 \mathrm{c}$ & 1.55 & $0.27 \mathrm{de}$ & 2.51 & $1.31 \mathrm{~b}$ & 0.38 & 6.09 & $894 c$ & $357.5 \mathrm{c}$ & $34.7 \mathrm{~b}$ \\
\hline $\mathrm{AM}+50 \% \mathrm{P}$ & 2.33 & $0.46 \mathrm{c}$ & 1.58 & $0.32 b$ & 2.72 & $1.45 \mathrm{a}$ & 0.46 & 6.66 & $950 \mathrm{bc}$ & $379.8 \mathrm{bc}$ & $38.6 \mathrm{a}$ \\
\hline $\mathrm{AM}+75 \% \mathrm{P}$ & 2.39 & $0.47 b c$ & 1.58 & $0.30 \mathrm{~b}-\mathrm{e}$ & 2.67 & $1.42 \mathrm{a}$ & 0.43 & 6.89 & $897 \mathrm{c}$ & $358.7 \mathrm{c}$ & $39.3 \mathrm{a}$ \\
\hline $\mathrm{AM}+100 \% \mathrm{P}$ & 2.36 & $0.50 \mathrm{bc}$ & 1.59 & $0.30 \mathrm{bc}$ & 2.76 & $1.47 \mathrm{a}$ & 0.45 & 6.72 & $910 \mathrm{c}$ & $364.1 \mathrm{c}$ & $39.4 \mathrm{a}$ \\
\hline Rhi. $+50 \% \mathrm{P}$ & 2.27 & $0.46 \mathrm{c}$ & 1.56 & $0.27 \mathrm{e}$ & 2.66 & $1.47 \mathrm{a}$ & 0.44 & 6.57 & $1031 \mathrm{ab}$ & $417.3 \mathrm{ab}$ & $37.5 \mathrm{a}$ \\
\hline Rhi. $+75 \% \mathrm{P}$ & 2.31 & $0.49 \mathrm{bc}$ & 1.57 & $0.30 \mathrm{~b}-\mathrm{d}$ & 2.75 & $1.46 \mathrm{a}$ & 0.41 & 6.82 & $1022 \mathrm{ab}$ & $408.8 \mathrm{ab}$ & $38.4 \mathrm{a}$ \\
\hline Rhiz. $+100 \% \mathrm{P}$ & 2.27 & $0.50 \mathrm{~b}$ & 1.58 & $0.29 b-e$ & 2.72 & $1.47 \mathrm{a}$ & 0.46 & 6.54 & $1032 \mathrm{ab}$ & $412.7 \mathrm{ab}$ & $39.5 \mathrm{a}$ \\
\hline $\mathrm{AM}+R h i .+50 \% \mathrm{P}$ & 2.38 & $0.56 \mathrm{a}$ & 1.59 & $0.28 \mathrm{c}-\mathrm{e}$ & 2.75 & $1.46 \mathrm{a}$ & 0.45 & 6.88 & $1070 \mathrm{a}$ & $427.8 \mathrm{a}$ & $39.5 \mathrm{a}$ \\
\hline $\mathrm{AM}+$ Rhi. $+75 \% \mathrm{P}$ & 2.40 & $0.57 \mathrm{a}$ & 1.59 & $0.30 \mathrm{~b}-\mathrm{d}$ & 2.79 & $1.48 \mathrm{a}$ & 0.43 & 6.78 & $1091 \mathrm{a}$ & $436.4 \mathrm{a}$ & $39.5 \mathrm{a}$ \\
\hline $\begin{array}{l}\mathrm{AM}+{ }^{+} \text {Rhi. }+ \\
100 \% \mathrm{P}\end{array}$ & 2.40 & $0.57 \mathrm{a}$ & 1.59 & $0.36 \mathrm{a}$ & 2.78 & $1.48 \mathrm{a}$ & 0.45 & 6.96 & $1077 \mathrm{a}$ & $430.5 \mathrm{a}$ & $39.5 \mathrm{a}$ \\
\hline $\mathrm{SE}( \pm)$ & 0.08 & 0.01 & 0.02 & 0.02 & 0.06 & 0.03 & 0.02 & 0.29 & 38.5 & 15.1 & 1.17 \\
\hline F-test & NS & $* *$ & NS & $* *$ & NS & $*$ & NS & NS & $* *$ & $* *$ & $* *$ \\
\hline $\mathrm{CV}(\%)$ & 5.03 & 5.57 & 3.09 & 7.19 & 4.43 & 4.45 & 7.54 & 6.09 & 7.72 & 7.54 & 4.29 \\
\hline
\end{tabular}

AM: Arbuscular mycorrhiza, Rhi.: Rhizobium. Control is not absolute control. The values represent means of 4 replicates. Different letters within each column indicate significant differences between treatments. Test CropStat and Statistix 10. **Significant $\mathrm{P} \leq 0.01$, *significant $\mathrm{P} \leq 0.05$, NS not significant.

The present results agree with Sharifi et al. (2007) who reported that the alfalfa specimens inoculated with both Rhizobium and Glomus produced the highest shoot yield and they concluded that Rhizobium may affect fungal metabolism. The results are also in line with other studies that have shown that inoculation of legumes with both rhizobium and AMF increases plant growth to a greater extent than either inoculum when added singly (Murakami et al., 1991). Soliman et al. (2012) observed that co-inoculation (AMF + R) enabled the plants (Acacia saligna) to maintain osmotic adjustments and enhanced the plants tolerance against salinity.

Effects of AM, Rhizobium and P on nodule number, nodule weight and root colonization of mungbean

Effect of AM, Rhizobium and $\mathrm{P}$ on nodule number, nodule weight and root colonization of mungbean are displayed in Fig. 3 and Fig. 4. Significant differences were found in case of nodule number plant ${ }^{-1}$, nodule weight $(\mathrm{mg}$ plant $^{-1}$ ) and root infection (\%) at 50\% flowering stage. The highest nodule number (21.3 plant $\left.^{-1}\right)$, nodule weight $\left(26.7 \mathrm{mg} \mathrm{plant}^{-1}\right)$ and root infection $(33.3 \%)$ at $50 \%$ flowering stage was found in $\mathrm{AM}+$ Rhizobium $+100 \% \mathrm{P}$ treatment. The 
lowest nodule number $\left(18.8\right.$ plant $\left.^{-1}\right)$, nodule weight $\left(18.3 \mathrm{mg}\right.$ plant $\left.^{-1}\right)$ and root infection $(13.3 \%)$ at $50 \%$ flowering stage was found in control treatment.

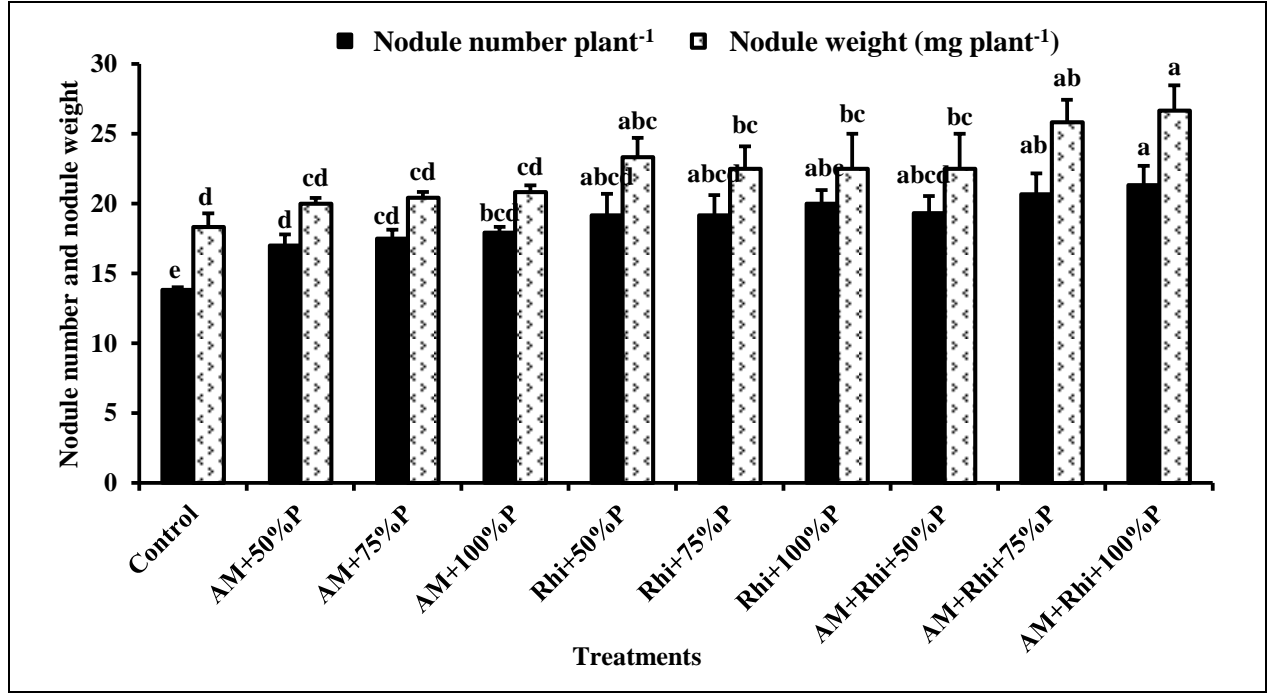

Fig. 3. Effects of AM, Rhizobium and $P$ on nodule number and nodule weight of mungbean in slightly saline soil.

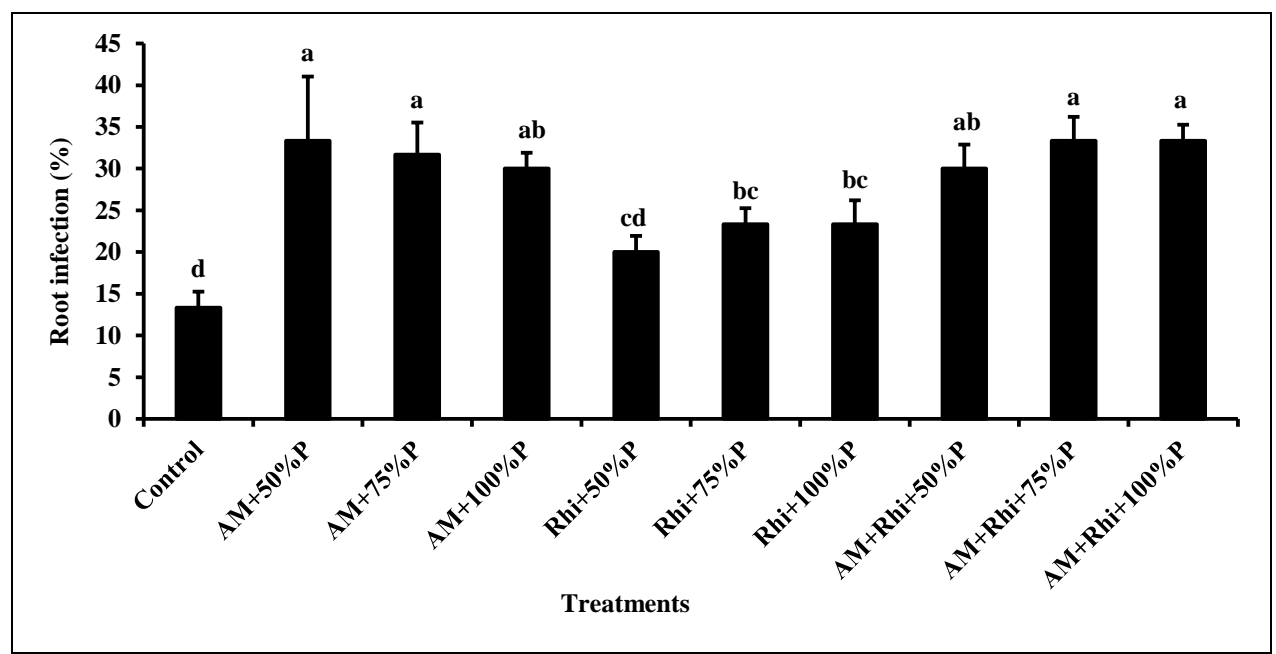

Fig. 4. Effects of AM, Rhizobium and $P$ on root infection (\%) of mungbean in slightly saline soil.

Soliman et al. (2012) reported that co-inoculated (AMF + Rhizobium) stressed plants enhanced nodulation parameters. Reduction in nodulation under salt stress could be due to a reduction in survival and multiplication of rhizobia cells (Elboutahiri et al., 2010). The reduction in the number and weight of nodules was less when the plants were double inoculated, compared to inoculation with 
rhizobium or mycorrhiza alone. This depicted that the harmful effect of salinity could be reduced by dual inoculation. Salinity decreased the hyphae growth and/or viability of AMF and also decreased respiration, survival probability, inhibited enzyme function and multiplication of the rhizobia cells in the substrates, which affect the process of root colonization and nitrogenase activity (Mahmood et al., 2008). In this present study, co-inoculated (AMF + Rhizobium) test plants showed less toxic effects of salts on nodulation parameters and mycorrhizal infection compared with control plants. This can be attributed to improve root growth. In addition, root exudation is modified both qualitatively and quantitatively by arbuscular mycorrhizal symbiosis and this has led to increase in nodulation parameters and mycorrhizal infection (Garg and Manchanda, 2009).

\section{Effect of AM, Rhizobium and $P$ on nutrient concentration of mungbean}

Effect of AM, Rhizobium and $\mathrm{P}$ on nutrient concentration of mungbean is exhibited in Table 4. Significant differences were found in case of P, S, Mg, Fe, $\mathrm{Mn}$ and $\mathrm{Zn}$ concentrations of mungbean but other nutrients not significant. The highest $\mathrm{P}$ concentration was found in $\mathrm{AM}+$ Rhizobium $+100 \% \mathrm{P}$ treatment and the lowest $\mathrm{P}$ concentration in control treatment. The highest $\mathrm{Mg}, \mathrm{Fe}, \mathrm{Mn}$ and $\mathrm{Zn}$ concentrations were found in $\mathrm{AM}+$ Rhizobium $+75 \% \mathrm{P}$ treatment and the lowest result in control treatment.

However, N, P, K, S, Zn and B concentrations of mungbean were higher in coinoculated plants at all $\mathrm{P}$ levels compared to sole-inoculated plants. Increased $\mathrm{N}$ and $\mathrm{P}$ supply resulting in an increase in nitrogen fixation can be suggested for the benefits of the synergistic relationship (Giri et al., 2002). Under salinity condition, the greatest amount of mycorrhizal infection, nodulation, $\mathrm{P}$ concentration and the root $\mathrm{Ca}$ concentration of alfalfa plants were recorded when plants were double inoculated. (Ashrafi et al., 2014).

This report therefore confirms that mycorrhizal-inoculated plants have alternative mechanisms to satisfy their nutritive requirement in stress situations. There are indications that a beneficial effect of AM fungi and Rhizobium in soil are due to the creation of soil conditions suitable for the growth of hyphae, increased microbial activity and increased mineral nutrient uptake specially $\mathrm{P}$ by plant.

\section{Conclusion}

Results of the experiment revealed that the highest yield of mungbean was found in AM + Rhizobium $+75 \%$ P treatment. Mungbean yield considerably increased under low salinity stress condition by increasing nodulation, colonization and nutrient uptake. Maximum increment was noted where $100 \%$ of the recommended $\mathrm{P}$ along with dual inoculation (AM + Rhizobium) was applied, however, it was statistically at par with the results recorded by $75 \%$ of recommended $\mathrm{P}$ along with dual inoculation of mycorrhiza and Rhizobium inoculum. 


\section{References}

Ashoori, M., S. Ashraf and Z. T. Alipour. 2015. Investigating the effect of two species of mycorrhiza fungi and salinity on growth, function and chlorophyll content on Ocimum basilicum. International J. Agric. and Crop Sci. 8(3): 503-509.

Ashrafi, E., M. Zahedi and J. Razmjoo. 2014. Co-inoculations of arbuscular mycorrhizal fungi and rhizobia under salinity in alfalfa. Soil Sci. Plant Nutr. 60: 619-629.

BARC (Bangladesh Agricultural Research Council). 2012. Fertilizer Recommendation Guide. Bangladesh Agricultural Research Council, Farmgate, New Airport Road, Dhaka-1215. Pp. 102.

BBS. 2017. Yearbook of Agricultural Statistics (28th Series). Bangladesh Bureau of Statistics. Statistics and Information Division. Ministry of Planning, Government of the People's Republic of Bangladesh, Pp. 101.

Black, C.A. 1965. Methods of Soil Analysis. Part I and II. American Soc. of Argon. Inc. Pub. Madison, Wisconsin, USA.

Chesnin, L. and C. H. Yien. 1950. Turbidimetric Determination of Available Sulphates. Soil Sci. Soc. America J. 15: 149-151.

Elboutahiri, N., I. Thami-Alami and S. M. Udupa. 2010. Phenotypic and genetic diversity in Sinorhizobium meliloti and S. medicae from drought and salt affected regions of Morocco. BMC Microbiol. 10: 15.

Garg, N., G. Manchanda. 2009. Role of arbuscular mycorrhizae in the alleviation of ionic, osmotic and oxidative stresses induced by salinity in Cajanus cajan (L.) Millsp. (Pigeonpea). J. Agron. Crop Sci. 195: 110-123.

Gerdemann, J. W. and T. H. Nicolson. 1963. Species of mycorrhizal endogone species extracted from soil by wet sieving and decanting method. Trans. Brit. Mycol. Soc. 46: $235-246$.

Giri, B., R. Kapoor and K. G. Mukerji. 2002. VA Mycorrhizal techniques/VAM technology in establishment of plants under salinity stress conditions. In: Techniques in mycorrhizal studies. (Eds.): K. G. Mukerji, C. Manoharachary \& B. P. Chamola. Netherlands: Kulwer, 313-327.

ISTA (International Seed Testing Association). 1976. International Rules for Seed Testing. Seed Sci. and Tech. 4: 3-49.

Jackson, M. L. 1962. Soil Chemical analysis. Constable and Co. Ltd. London.

Jackson, M. L. 1958. Soil Chemical Analysis. Constable and Co. Ltd., London.

Jamil, A., S. Riaz, M. Ashraf and M. R. Foolad. 2011. Gene expression profiling of plants under salt stress. Crit. Rev. Plant Sci. 30(5): 435-458.

Koide, R. T. 1991. Nutrient supply, nutrient demand and plant response to mycorrhizal infection. New Phytol. 117: 365-386.

Koide, R. T. and M. Li. 1990. On host regulation of the vesicular-arbuscular mycorrhizal symbiosis. New Phytol. 114: 59-65. 
Mahmood, A., A. Mohammad, Q. Raiha and M. Nadeem. 2008. Effect of NaCl salinity on growth, nodulation and total nitrogen content in Sesbania sesban. ACS. 73: 137141.

Mendez, E. M., M. Leiva-Mora, E. K. D. Jayawardana, L. García, N. Veitía, I. Bermúdez-Caraballoso, R. Collado, R. C. Ortíz. 2015. Effect of salt stress on seed germination and seedlings growth of Phaseolus vulgaris L. Cultivos Tropicales. 36(3): Pp. 71-74.

Murakami, M., Y., Y. Yamamoto and S. Yamaki. 1991. Analyses of indole acetic acid and absclsic acid contents in nodules of soybean plants bearing VA mycorrhizas. Soil Sci. Plant Nutr. 37: 291-298.

Olsen, S. R., C. V. Cole, F. S. Watanabe and L. A. Dean. 1954. Estimation of available phosphorus in soils by extraction with sodium bicarbonate. U.S. Dept. Agric. Circ. Pp. 939.

Rahman, M., M. A. H. Bhuiyan, M. E. Ali, F. Alam and R. A. Begum. 2017. Effect of Arbuscular Mycorrhizal Fungi on the Tolerance to Sodium Chloride Levels, and on Growth and Yield of Lentil (Lens culinaris). The Agriculturists. 15(1):156-169.

Read, D. J., H. K. Koucheki and J. Hodgaon. 1976. Vesicular arbuscular mycorrhiza in natural vegetation systems. New Phytol. 77: 641-653.

Schwarzott, D., C. Walker and A. Schussler. 2001. Glomus, the largest genus of the arbuscular mycorrhizal fungi (Glomales), is nonmonophyletic. Mol. Phylogenet. Evol. 21:190-197.

Sharifi, M., M. Ghorbanli and H. Ebrahimzadeh. 2007. Improved growth of salinitystressed soybean after inoculation with salt pre-treated mycorrhizal fungi. J. Plant Physiol. 164: 1144-1151.

Soliman, A. S., N. T. Shanan, O. N. Massoud and D. M. Swelim. 2012. Improving salinity tolerance of Acacia saligna (Labill.) plant by arbuscular mycorrhizal fungi and Rhizobium inoculation. African J. Biotech. 11(5): 1259-1266.

SRDI. 2010. Saline soils of Bangladesh. SRMAF Project, Ministry of Agriculture, Dhaka, Bangladesh. Pp. 1-60.

Walkey, A. and I. A. Black. 1934. An examination of degtiareff method for determining soils organic matter and a proposed modification of the chromic acid titration method. Soil Sci. 37: 29-38.

Zedler, J. B., H. Morzaria-Luna and K. Ward. 2003. The challenge of restoring vegetation on tidal, hypersaline substrates. Plant Soil. 253:259-273. 
